\title{
Fungal Profile of Occular Infection in Patients Attending In a Tertiary Care Hospital
}

\author{
Namitha $\mathrm{Bn}^{1}$, Mahalakshmi ${ }^{2}$ \\ Dep Of Microbiology,Navodaya Medical College,Raichur
}

\begin{abstract}
Aim and objective: To identify the fungal etiology of Ocular infections in patients attending Ophthalmology department from the period Nov 2010 to Sep 2011 at Navodaya Medical College Hospital and Research Centre, Raichur.

Methods: 102 patients attending Ophthalmology OPD/IPD in Navodaya Medical College Hospital and Research Centre were analysed from Nov 2010 to Sep 2011. Using predefined inclusion and exclusion criteria, samples were collected according to the standard protocol. These were cultured for microorganisms (fungal) and were identified.
\end{abstract}

Results: Out of 102 samples studied, 75 samples had growth and the isolation rate. only 23(26\%) was fungal growth. KOH wet mount examination showed high specificity of $98.73 \%$ and PPV of $90.91 \%$ with very significant $p$ value of $<0.0001$. The most common fungal isolate were Fusarium spp (30.43\%) followed by Aspergillus spp (26.04\%).

Conclusion: Fungal etiology was mostly associated with corneal infections. Direct microscopic examination is an essential tool in the diagnosis of fungal infections. A simple and rapid $\mathrm{KOH}$ wet mount examination early during the disease result in significant progress of the disease in initiating early and specific therapy.

Keywords: Ocular infections, potassium hydroxide wet mount, Fusarium

\section{Introduction}

Eye is the most important sensory organ concerned with the perception of vision. ${ }^{1}$ Ocular infections can affect different eye structures and their presentation and treatment vary accordingly ${ }^{1}$ and present as: blepharitis, conjunctivitis, canaliculitis, Dacrocystitis, keratitis, scleritis, orbital cellulitis, endopthalmitis, panophthalmitis and other infections which are responsible for increased incidence of morbidity and blindness worldwide, their morbidity vary from self limiting trivial infection to sight threatening infection. ${ }^{2}$

An estimated 38 million people worldwide are blind, and 110 million have low vision. Extrapolations from data summarized by the World Health Organization (WHO) and other sources suggest that nearly 10 million people are visually disabled as a result of infectious diseases, which account for about one fourth of the world's blindness. ${ }^{3}$

India is a tropical agricultural country having higher prevalence of fungal keratitis compared to European and other western countries. ${ }^{4}$

Keratitis is the most frequently encountered fungal infections, although the orbit, lids, lacrimal apparatus, sclera, conjunctiva and intraocular structures may also be involved. ${ }^{5}$

Timely institution of appropriate therapy must be initiated to control the infections and there by minimize the ocular morbidity. If they are not treated promptly, it may lead to sight threatening condition. For specific antimicrobial treatment identification of the causative agent is important. ${ }^{6}$

Culture and direct microscopy are the two important investigations that are widely used. Culturing of microbial pathogens is considered to be the gold standard whereas direct microscopic evaluation of smears provides immediate information about the causative organisms for initiating treatment. ${ }^{7,8}$

\section{Patients And Methods}

The present study was undertaken at Navodaya Medical College Hospital and Research centre, Raichur which included 102 cases during the period November 2010 to September 2011. The subjects in this study included those who were clinically diagnosed cases of ocular infections attending Outpatient Department and Inpatient Department of Ophthalmology, Tertiary Care Centre (Navodaya Medical College Hospital and Research Centre), Raichur and patients who are not on antibiotics (either topical or systemic) or patients not responding to antibiotics.

\section{Sample collection ${ }^{9}$}

After clinical diagnosis of ocular infection made by Ophthalmologist, specimens were collected with the help of Ophthalmologist. 
Eye lid swab was collected using sterile cotton tipped swab moistened with sterile peptone water which was rolled over the eye lid margin from medial to lateral side and back again.

Conjunctival swab was collected using dry sterile cotton tipped swab by asking the patient to look up, the lower lid was pulled down using thumb with an absorbing tissue paper and the swab was rubbed over the lower conjunctival sac from medial to lateral side and back again.

Pus from lacrimal sac was collected using dry sterile cotton tipped swab either by applying pressure over the lacrimal sac and allowing the purulent material to reflux through the lacrimal punctum or by irrigating the lacrimal drainage system with sterile saline called as Lacrimal Syringing and collecting the sample from the refluxing material ensuring that the lid margins or the conjunctiva were not touched.

In cases of acute lacrimal abscess on chronic Dacrocystitis pus was drained and taken on a dry sterile cotton tipped swab.

Corneal scrapings was collected after instilling 2 to 3 drops of local anesthetic into the conjunctiva, patient is asked to wait for 2 to 3 min and corneal surface was cleaned for debris and discharge using dry sterile cotton tipped swab and with the help of slit lamb the edge of the ulcer was scraped using sterile disposable scalpel blade no 15 taking care not to perforate the cornea.

The number of swabs and scrapings collected depended on the material obtained on swab stick or the blade, at least a minimum of 2 swabs or scrapings and maximum of 4 swabs or scrapings were collected.

The corneal button, the lacrimal sac, chalazion removed by surgery was sent to the microbiology laboratory in a sterile container filled with sterile normal saline immediately

The corneal button and the lacrimal sac tissue were labeled and processed after cutting into small bits using sterile scalpel blade and sterile forceps in a small sterile petridish following all aseptic precautions and processed immediately

\section{Laboratory Diagnosis:}

Direct smear examination:

KOH wet mount preparation: one swab was spread or sample material was placed on a clean grease free glass slide over which a drop of $10 \% \mathrm{KOH}$ solution was placed and covered with a cover slip. After about 15 to 20 min the slide was examined under dry objectives for the presence of fungal elements like hyphae, pseudohyphae, yeast cells, spores, spherules or sclerotic bodies.

Gram stain: was done to look for gram positive budding yeast cell, hyphae, pseudohyphae.

\section{Fungal culture:}

The specimens (swab) was used to inoculate on two Sabouraud Dextrose Agar plates with antibiotics but without actidione in a "C" shaped streak and incubated at $25^{\circ} \mathrm{Cand}$ at $37^{\circ} \mathrm{C}$, they were examined daily for any growth for the first week and twice a week for a period of four weeks and if any growth on SDA, the identification was done as below.

\section{Isolation of fungi:}

The growth was observed for the following -

Rate of growth, Morphology of colony, Texture, Surface pigmentation, Microscopic examination like LPCB mount and slide culture were done to identify the fungi.

No growth was observed even after 3 weeks of incubation, the culture was considered as sterile and the plates were discarded.

\section{Statistical Analysis:}

Descriptive statistics was used such mean, standard deviation and proportion. Chi-square test or Fisher's exact test for small sample size was used to find out the relationship between categorical variables. A $p$ value less than 0.05 were considered as significant and 0.01 as highly significant. Data were analyzed by SPSS v16.0 software.

Table 6: Total number of Bacterial and Fungal growth

\begin{tabular}{|l|l|}
\hline Total isolates & 87 \\
\hline Bacteria & $64(74 \%)$ \\
\hline Fungus & $23(26 \%)$ \\
\hline
\end{tabular}

Of the total 87 isolates64 (74\%) is bacterial growth; only $23(26 \%)$ is fungal growth. 


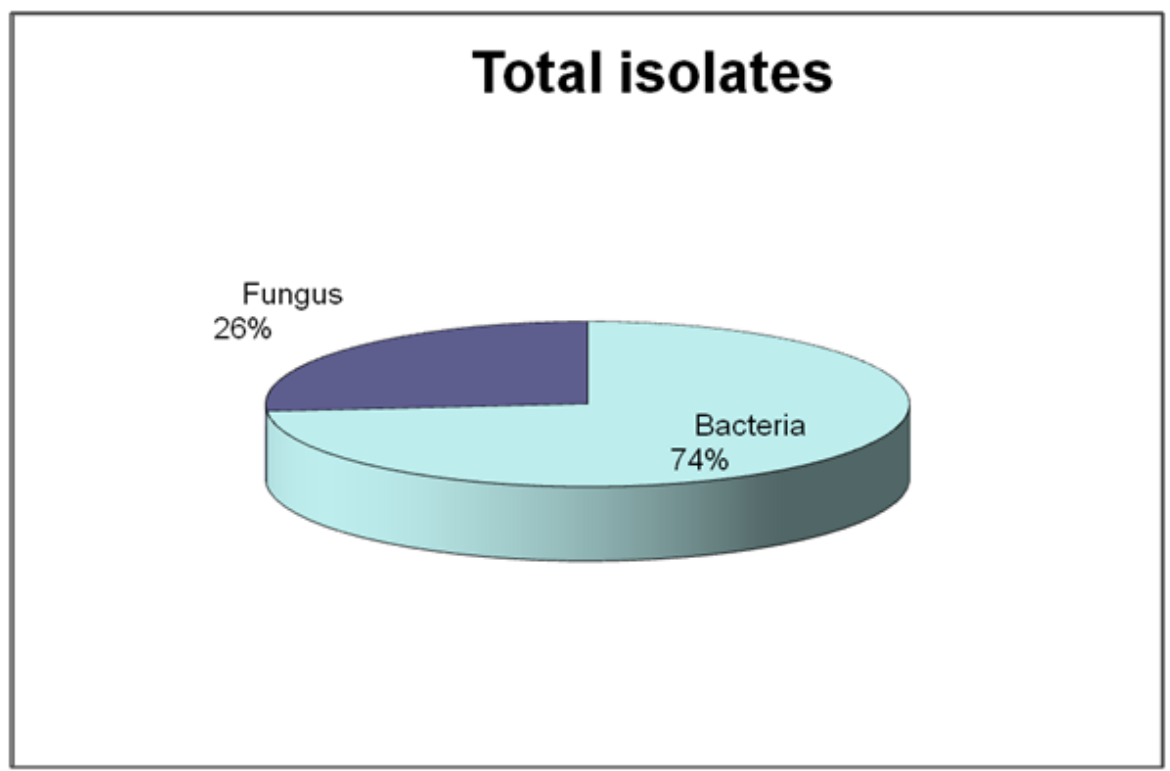

Graph 5 showing the distribution of bacterial and fungal isolates

Table 8: Correlation of $\mathrm{KOH}$ with Culture Results.

\begin{tabular}{|l|l|l|l|}
\hline \multirow{2}{*}{ KOH } & \multicolumn{2}{|l|}{ Culture } & \multirow{2}{*}{ Total } \\
\cline { 2 - 3 } & Positive & Negative & \\
\hline Positive & 10 & 1 & 11 \\
\hline Negative & 13 & 78 & 91 \\
\hline Total & $\mathbf{2 3}$ & $\mathbf{7 9}$ & $\mathbf{1 0 2}$ \\
\hline
\end{tabular}

$. X^{2}=28.75, \mathrm{df}=1, \mathrm{p}<0.0001$

Sensitivity and specificity

Variable

Value

Sensitivity

$43.48 \%$

Specificity

$98.73 \%$

Positive Predictive Value

$90.91 \%$

Negative Predictive Value

$85.71 \%$

Out of $11 \mathrm{KOH}$ positives, 10 correlated with culture results, out of $91 \mathrm{KOH}$ negatives 13 was positive for culture results with high specificity of $98.73 \%$ and sensitivity of $43.48 \%$ with highly significant $p$ value of < 0.0001 .

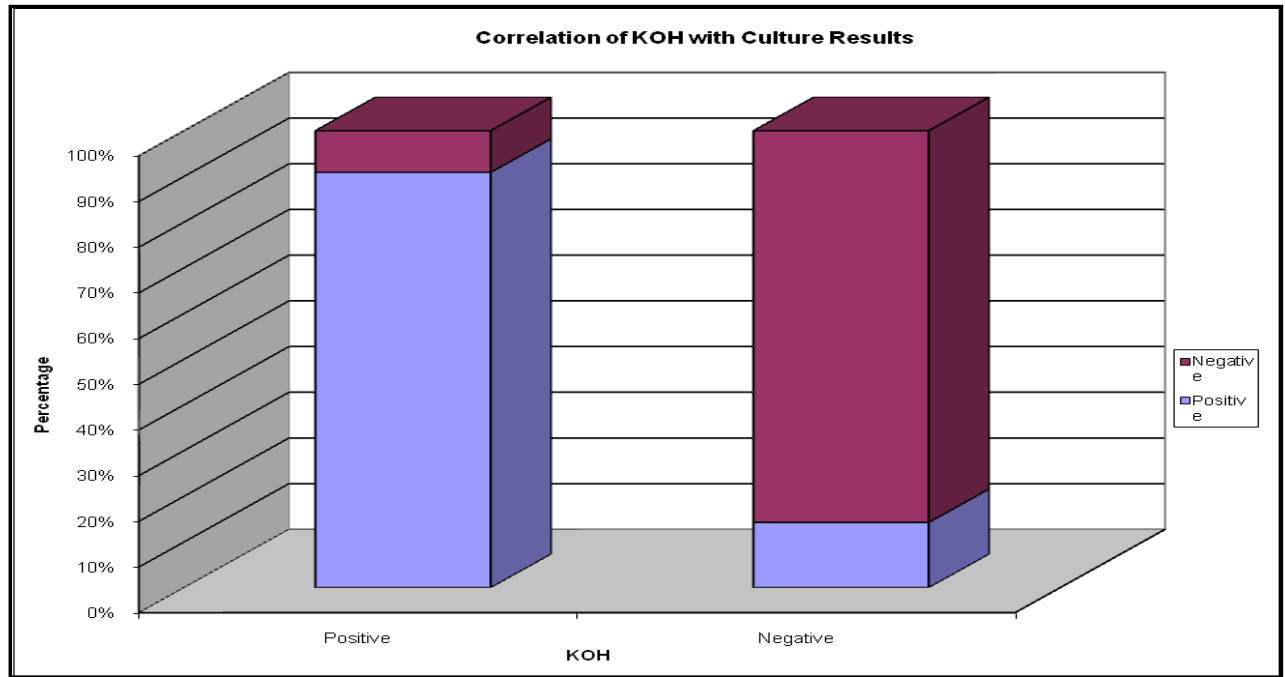

Graph 7 showing the correlation of $\mathrm{KOH}$ results with culture results 
Table 14: Distribution of fungal isolates according to their spectrum.

\begin{tabular}{|l|l|l|}
\hline Fungal isolates & Number of isolates & Percentage \\
\hline Aspergillus niger & 1 & 4.35 \\
\hline Aspergillus fumigates & 2 & 8.70 \\
\hline Aspergillus flavus & 3 & 13.04 \\
\hline Fusarium spp & 7 & 30.43 \\
\hline Rhizopus spp & 4 & 17.39 \\
\hline Mucor spp & 2 & 8.70 \\
\hline Alternaria spp & 2 & 8.70 \\
\hline Unidentified filamentous fungi & 2 & 8.70 \\
\hline Total & $\mathbf{2 3}$ & $\mathbf{1 0 0}$ \\
\hline
\end{tabular}

Out of 87 isolates, 23(26\%) is the fungal isolates and the most common is Fusarium spp 7(30.43\%) followed by Aspergillus spp 6(26.09\%) and among this Aspergillus spp, Aspergillus flavus is 3(13.04\%), Aspergillus fumigatus 2(8.7\%) and Aspergillus niger 1(4.35\%), Rhizopus spp is 4(17.39\%), Mucor sp, Alternaria spp and unidentified filamentous fungi $2(8.7 \%)$ each.

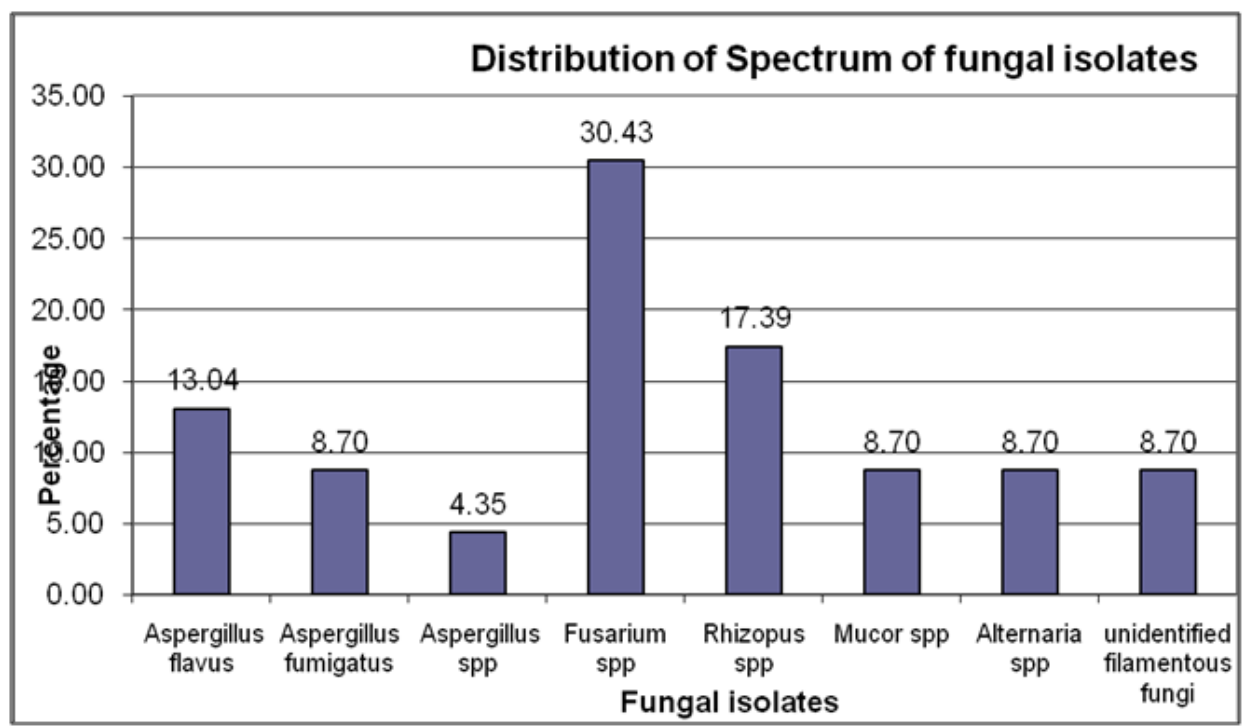

Graph 13 Distribution of organism wise fungal isolates

Table 15: Sample wise distribution of organisms

\begin{tabular}{|c|c|c|c|c|c|c|c|c|c|c|}
\hline Organisms & $\begin{array}{l}\text { Eye lid } \\
\text { swab }\end{array}$ & $\begin{array}{l}\text { Excised } \\
\text { Chalazio } \\
\text { n tissue }\end{array}$ & $\begin{array}{l}\text { Conju } \\
\text { nctival } \\
\text { swab }\end{array}$ & $\begin{array}{l}\text { Pus from } \\
\text { Dacrocys } \\
\text { titis }\end{array}$ & $\begin{array}{l}\text { Lacrimal } \\
\text { Sac tissue }\end{array}$ & $\begin{array}{l}\text { Corne } \\
\text { al } \\
\text { button }\end{array}$ & $\begin{array}{l}\text { Corn } \\
\text { eal } \\
\text { scrap } \\
\text { ings }\end{array}$ & $\begin{array}{l}\text { Corn } \\
\text { eal } \\
\text { swab }\end{array}$ & $\begin{array}{l}\text { Pus swab } \\
\text { from } \\
\text { orbital } \\
\text { cellulitis }\end{array}$ & Total \\
\hline Aspergillus niger & & & & & & & 1 & & & 1 \\
\hline Aspergillus flavus & & & & & & & 2 & 1 & & 3 \\
\hline $\begin{array}{l}\text { Aspergillus } \\
\text { fumigatus }\end{array}$ & & & & & & & 1 & 1 & & 2 \\
\hline Fusarium spp & & & & & & & 4 & 3 & & 7 \\
\hline Rhizopus spp & & & & 1 & & & 3 & & & 4 \\
\hline Mucor spp & & & 1 & & & & 1 & & & 2 \\
\hline Alternaria spp & & & & 1 & & 1 & & & & 2 \\
\hline $\begin{array}{l}\text { Unidentified } \\
\text { filamentous fungi }\end{array}$ & & & & & & & 1 & 1 & & 2 \\
\hline Total & & & 1 & 2 & & 1 & 13 & 6 & & 23 \\
\hline PERCENTAGE & & & 4.3 & 8.6 & & 4.3 & 56.5 & 26 & & 100 \\
\hline
\end{tabular}

\section{Results}

Of the102 samples studied, 23(26\%) was the fungal growth among the total isolates of 87 . Out of these 23 isolates 11 was positive for $\mathrm{KOH}$ wet mount. Out of these $11 \mathrm{KOH}$ positives, 10 correlated with culture results and 13 was positive for culture results and $\mathrm{KOH}$ negative which showed high specificity of $98.73 \%$ and sensitivity of $43.48 \%$ with highly significant $\mathrm{P}$ value of $<0.0001$.

Among the patients with fungal isolates, 10 were female patients and 13 were male patients. The mean $+\mathrm{SD}$ age of the patients was +15.84 (range 6yrs- 75yrs). 21 isolates were from corneal sample (corneal 
scrapings, corneal swab, and corneal button). Only 2 isolates were from pus (chronic Dacrocystitis and canaliculitis abcess)

The most common fungal isolate was Fusarium species 7(30.43\%) followed by Aspergillus species 6(26.09\%). Among these Aspergillus species, Aspergillus flavus was 3(13.04\%), Aspergillus fumigatus 2(8.7\%) and Aspergillus niger 1(4.35\%). Rhizopus species was 4(17.39\%), Mucor species, Alternaria species and unidentified filamentous fungi $2(8.7 \%)$ each.

\section{Discussion}

Ocular infections are one of the common reasons in ophthalmic clinics or hospital attendance. Bacteria are the common cause of ocular morbidity, whereas viral and fungal infections are much less common.

The growth characteristics of the fungus can result in superficial infection or invasion into deep tissues. Effective therapy of such infections must be selected from the small number of antifungal agents and requires recognition of the limitations of susceptibility testing, the importance of tissue penetration and absorption, and the need for protracted treatment. Because of these limitations, success of therapy primarily depends on early diagnosis of fungal infection and correct identification of particular fungus. ${ }^{10}$

Corneal infection of fungal etiology is very common and represents $30-40 \%$ of all cases of culture positive infectious keratitis in south India ${ }^{11}$

In the present study of the 102 clinically diagnosed cases of ocular infections fungal isolates were only $26 \%$ where as bacterial isolates was $74 \%$ this was in comparison to study by Kunimoto et al ${ }^{12}$, Garg et al ${ }^{13}$, Dunlop et $\mathbf{a l}^{14}$ and Upadhyay et $\mathbf{a l}^{15}$ where the bacteria: fungal isolates are $74 \%: 25.7 \%, 63.62 \%: 33.64 \%$, $53.50 \%: 35.90 \%$, and $63.2 \%: 6.7 \%$ respectively.

In other study by Sherwal B $\mathbf{L}$ et al ${ }^{\mathbf{1 6}}$ and $\mathbf{~ L e c k ~ e t ~} \mathbf{a l}^{\mathbf{1 7}}$ fungal isolates were more than bacterial isolates, bacteria : fungal isolates are $20.84 \%: 32.50 \%$ and $23.9 \%: 38.6 \%$.

In our study the fungal isolates were mostly from the corneal sample. The lower temperature of the cornea relative to the rest of the body and eye, and its exposure to potential trauma, may partially explain why keratomycosis is the most common ocular fungal infection. ${ }^{10}$

Among the 23 patients with fungal isolates 13(56.5\%) were male and 10(43.4\%) were female. There was not much difference in the sex ratio, though there was a male predominance. This correlates with the study of Bharathi et $\mathbf{a l}^{18}$, Srinivasan $\mathrm{M}$ et $\mathbf{a l}^{\mathbf{1 9}}$, Chowdhary et al ${ }^{20}$ and Shokohi et al. ${ }^{21}$

The mean age of the patients with fungal isolates was 48yrs (range 6yrs - 75yrs). This is comparable with the study of Samar $\mathbf{K}$ Basak et $\mathbf{a l}^{\mathbf{8}}$. The age distribution showed the incidence of fungal keratitis predominantly between the $4^{\text {th }}$ to $6^{\text {th }}$ decades, reflecting the active working period of life and hence the increased vulnerability to injury during outdoor activities.

In the present study $\mathrm{KOH}$ examination is positive for fungal elements in 11 samples whereas it is negative in 91 samples, $\mathrm{KOH}$ and culture results correlated in 88 samples showing high specificity of $98.73 \%$ and PPV of $90.91 \%$ with very significant $p$ value of $<0.0001$. In a study by Sharma VK et $\mathbf{a l}^{22}$ out of $16.9 \%$ $\mathrm{KOH}$ positive $\mathbf{1 5 . 4 \%}$ was culture positive, in the study by Laila $\mathbf{A}$ et $\mathbf{a l}^{\mathbf{2 3}}$ and Vajpayee RB et $\mathbf{a l}^{\mathbf{2 4}}$ the diagnostic significance of $\mathrm{KOH}$ was $84.85 \%$ and $94.3 \%$ respectively.

In a study by Gopinathan $\mathbf{U}$ et $\mathbf{a l}^{\mathbf{2 5}} \mathrm{KOH}$ was positive in $91.0 \%$ of $95.4 \%$ fungal isolates, study by Sharma $\mathbf{S}$ et $\mathbf{a l}^{\mathbf{2 6}}$ the sensitivity \& specificity of fungal detection was $81.2 \%$ \& $83.8 \%$ respectively. In another study by Sharma $\mathbf{S}$ et $\mathbf{a l}^{27}$ the sensitivity \& specificity of fungal detection in early and late keratitis was $61.1 \%$ $\& 99.0 \%$ and $87.1 \%$ \& $83.7 \%$ respectively. In a study by Jain AK et al ${ }^{28}$ the sensitivity was $100 \%$ and specificity was $46.67 \%$.

$\mathrm{KOH}$ wet mount preparation continues to be an ideal technique for revealing fungal elements in smears of corneal scrapings, considering the cost effectiveness, easy availability of reagents, ease of preparation of the reagents, sensitivity of method and rapidity of the test it helps in early introduction of appropriate antifungal drug by the ophthalmologist to prevent morbidity from corneal ulcers. ${ }^{25}$

In the present study the most common fungal isolate is Fusarium spp (30.43), followed by Aspergillus spp (26.09\%), Rhizopus spp (17.39\%), Mucor spp, Alternaria spp, and unidentified filamentous fungi $8.70 \%$ each.

In the study by Gopinathan $\mathbf{U}$ et $\mathbf{a l}^{\mathbf{2 5}} \mathbf{\&}$ Srinivasan $\mathbf{M}$ et $\mathbf{a l} \mathbf{l}^{\mathbf{1 9}}$, Fusarium was the most common isolate with $37.2 \%$ \& $47.1 \%$ isolation respectively and Aspergillus spp being the second common isolate with $30.7 \%$ \& $16.1 \%$ isolation respectively. The present study is getting correlated with Gopinathan $\mathbf{U}$ et $\mathbf{a l}^{\mathbf{2 5}}$ with Fusarium $\operatorname{spp}(30.43 \%)$.

In the present study $8.70 \%$ isolates were unidentified similar to other study by Kunimoto DY et $\mathbf{a l}^{\mathbf{1 2}}$ where the percentage of unidentified spp was $9.5 \%$.

In a study by Laila $\mathbf{A}$ et $\mathbf{a l}^{\mathbf{2 3}}$, the fungal spp isolated correlated with the present study \& these fungal isolates were Fusarium spp (24.24\%), Aspergillus spp (45.45\%), Alternaria spp (03.03\%), Mucor spp (12.1\%), Rhizopus spp (06.06\%) along with unidentified filamentous fungi (09.09\%). 

A et al. $^{23}$

Isolation of Aspergillus was more compared to Fusarium spp in studies by Sherwal BL et al ${ }^{\mathbf{1 6}} \&$ Laila

In our study there was no yeast isolated because Candida infection predominates in colder climates. Sharma $S$ et al. ${ }^{26}$

\section{Conclusion}

Ocular infections are the major cause of ocular morbidity and mortality which is a major public health problem in terms of visual compromise especially in developing countries like India. Fungal infections of the eye are seen mostly in the cornea with male predominance. $\mathrm{KOH}$ wet mount examination has good sensitivity and specificity for early diagnosis of fungal infections. Early and rapid identification of pathological organism is the key to ensuring successful medical therapy for fungal infections

\section{Bibliography}

[1]. Thielen TL, Castle SS, Terry JE. Anterior Ocular Infections: an overview of pathophysiology and treatment. Ann Pharmacother 2000; 34(2): 235- 246.

[2]. Chirambo MC, Tielsch JM, West KP, Katz J. Blindness and visual impairment in Southern Malawi. BULL WHO 1986; 64:567-72.

[3]. The World Health Report 1996: Fighting disease, fostering development. World Health Forum. 1997; 18:1-8.

[4]. Deshpande SD, Koppikar GV. A study of mycotic keratitis in Mumbai. Indian J Pathol Microbiol 1999; 42(1):81-87.

[5]. Srinivasan R, Kanungo R, Goyal JL. Spectrum of Oculomycosis in South India. Acta Ophthalmol 1991; 69:744-9.

[6]. Ramesh S, Ramakrishnan R, Bharathi MJ, Amuthan M, Vishwanathan S. Prevalence of bacterial pathogens causing ocular infections in South India. Indian J Pathol Microbiol 2010; 53:281-6.

[7]. Jagadesh Chander, Oculomycosis Text Book of Medical Mycology, $3^{\text {rd }}$ Edn, pp 400- 404, Mehta publishers A-16(East) Naraina 11, New Delhi- 110028, India.

[8]. Samar K Basak, Sukumar Basak, Ayan Mohanta, Arun Bhowmick- Epidemiological and Microbiological diagnosis of suppurative keratitis in Gangetic West Bengal, Eastern India. Indian J Ophthalmol 2005; 53: 17-22.

[9]. Gilmore MN, Chistopher N, Bowman RW, McCulley JP. Ocular Bacteriology Chapter 11 In: Albert DM, Miller JW, Azar DT, Blodi BA, Cohan JE, Perkins T. Albert \& Jakobiec's Principles and Practice of Ophthalmology 3rd edition Volume 1.Saunders Elsevier; 2008:101-116.

[10]. Schell WA, Foulks GN, Perfect JR. Fungal infections of eye Chapter 15 In: Albert DM, Miller JW, Azar DT, Blodi BA, Cohan JE, Perkins T. Albert \& Jakobiec's Principles and Practice of Ophthalmology 3rd edition Volume 1.Saunders Elsevier; 2008:159-168.

[11]. Agarwal V et al, Current perspectives in infectious keratitis. Indian J Ophthalmol 1994; 42: 171-191.

[12]. Kunimoto DY, Sharma S, Garg P, Gopinathan U, Miller D, Rao GN. Corneal ulceration in the elderly in Hydrabad, South India. Br J Ophthalmol 2000; 84:54-59.

[13]. Garg P, Rao GN. Corneal ulcer: diagnosis and management. Community eye health 2000; 12:21-24.

[14]. Dunlop AAS, Wright ED, Howlader SA, Nazrul I, Hussain R, McClellan K. Suppurative corneal ulceration in Bangladesh. Aus NZ J Ophthalmol 1994; 22:105-10.

[15]. Upadhyay MP, Kamacharya P, Koirali ST. Epidemiological characteristics predisposing factors and etiological diagnosis of corneal ulceration in Nepal. Am J Ophthalmol 1991; 111: 92-99.

[16]. Sherwal BL, Verma AK. Epidemiology of ocular infection due to bacteria and fungus. A prospective study. JK Science 2008; 10(3):127-131.

[17]. Leck AK, Thomas PA, Hagan M. Etiology of suppurative corneal ulcers in Ghana and South India and epidemiology of fungal keratitis. Br J Ophthalmol 2002; 86:1211-15.

[18]. Jayahar Bharathi M, Ramakrishna R, Samala Vasu, Meenakshi R, Palani Appan R Epidemiological charecteristics and laboratory diagnosis of fungal keratitis. Indian J Ophthalmol 2003; 51: 315-21.

[19]. Srinivasan M, Gonzales CA, George C, Cevallos V, Mascarenhas JM, Ashokan B et al . Epidemiology and etiological diagnosis of corneal ulceration in Madurai, South India. Br J Ophthalmol 1997; 81:965-971.

[20]. Thomas PA- Fungal infections of cornea. Eye 2003; 17: 852-62.

[21]. Shokohi T, Dailami K N, Haghighi T M, Fungal keratitis in patients with corneal ulcer in SARI, Northern Iran. Arch Iran Med 2006; 9(6): 222-7.

[22]. Sharma VK, Purohit M, Vaidya S. Epidemiological study of mycotic keratitis. The Internet Journal of Visual Science 2009; 6(2).

[23]. Laila A, Salam MA, Nurjahan B, Intekhab R, Sufikul I, Iftikhar A. Potassium Hydroxide wet preparation for the laboratory diagnosis of suppurative corneal ulcer. Bangladesh Journal of Medical Science 2010; 9(1): 27-32.

[24]. Vajpayee RB, Angra SK, Sandramouli S, Honavar SG, Chabra VK. Laboratory diagnosis of keratomycosis. Comparative evaluation of direct microscopy and culture results. Ann Ophthalmol 1993; 25:68-71.

[25]. Gopinathan U, Garg P, Fernandes M, Sharma S, Athmanathan S, Rao GN. The epidemiological features and laboratory results of fungal keratitis. Cornea 2002; 21(6):555-559.

[26]. Sharma S, Silverberg M, Mehta P, Gopinathan U, Agarwal V, Naduvilath TJ. Early diagnosis of mycotic keratitis. Predictive value of Potasium hydroxide preparation. Indian J Ophthalmol 1998; 46:31-5.

[27]. Sharma S, Garg P, Gopinathan U, Athmanathan S, Rao GN. Evaluation of corneal scraping smear methods in the diagnosis of bacterial and fungal keratitis: A Survey of eight years of Laboratory experience Cornea 2002; 21:643-647.

[28]. Jain AK, Bansal R, Felcida V, Rajwanshi A. Evaluation of impression smear in the diagnosis of fungal keratitis. Indian J Ophthalmol 2007; 55:33-6. 